\title{
4
}

\section{The Primary Education Teacher about ICT and Special Educational Needs. A Study in the Spanish Context}

\author{
José M. Fernández Batanero \\ batanero@us.es \\ Orcid: 0000-0003-4097-5382 \\ University of Seville
}

\begin{abstract}
One of the main challenges of international organizations, specialized in educational issues, is the measurement and diagnostic of teachers' digital competences, both in primary and secondary education. Within this context, and with the aim of looking at one of these theoretical premises, this study aimed to identify the degree of training and technological knowledge of primary school teachers in Spain with respect to the use of ICT with individuals with disabilities (functional diversity). A descriptive ex post-facto research method was used, where the sample comprised 777 teachers. An ad-hoc questionnaire was used as the data-collection instrument. The results revealed the low skill levels of the teachers with respect to the use of ICT with students with disabilities, where the level of training of the teaching staff was determined by personal (gender, age), professional (teaching experience) or educational (qualifications) variables. Among the conclusions, we highlight that teachers highly believe that ICT are useful resources for the training of people with disabilities. However, their technical management and educational use of the ICT, computers and the Internet had an effect on the knowledge they mentioned having on the use of the ICT with individuals with disabilities. This knowledge was not sufficient, according to the teaching staff. Also, the female teachers were perceived as having more knowledge than the male teachers.
\end{abstract}

Keywords: information and communication technologies, disability, educational inclusion, accessibility 


\subsection{Introduction}

The work was financed by the Spanish Ministry of Economics and Competitiveness within the State Plan for the Fomenting of Scientific and Technical Research of Excellence 2013-2016 (DIFOTICYD EDU2016 75232-P).

According to the Education at a Glance 2015 report, information and communication technologies (ICT) are an important component of economic growth in all OECD countries. Given the need of today's young people to competently use these technologies as students, as job applicants or workers, as consumers and as responsible citizens, those who do not have access to them or lack experience in their use find more and more difficult to take part fully in economic, social and civic life. However, the basic skills in ICT cannot add value unless they are accompanied by cognitive and other skills, such as those related to communication, creativity, teamwork and perseverance.

The teaching practices that teachers follow can play an important role in the degree of student learning.

One of the main challenges of international organizations, specialized in educational issues, is the measurement and diagnostic of teachers' digital competences, both in primary and secondary education. Along these lines, there have been many investigations and reports, both national and international, that have achieved to define different standards and the development of digital competence indicators. These studies have served as a reference and have encouraged the creation of other studies focused on the systematization of digital competence in an increasingly diverse society. This diversity can generate contexts of inequality if the formation of those that should favour the inclusion is not adequate.

Information and communication technologies (ICT) are an important component of economic growth in all OECD countries. Given the need of today's young people to competently use these technologies as students, as job applicants or workers, as consumers and as responsible citizens, those who do not have access to them or lack experience in their use find more and more difficult to take part fully in economic, social and civic life. However, the basic skills in ITC cannot add value unless they are accompanied by cognitive and other skills, such as those related to communication, creativity, teamwork and perseverance. 
Thus, the educational discourse on information and communication technologies (ICT) is deeply rooted on the premise that these are tools that favor the development, inclusion and participation of collectives that have been traditionally excluded.

The ICT facilitate the easy and comfortable access to all types of information; favor the student's autonomy, through their adaptation to the student's needs and demands; contribute to synchronous and asynchronous communication of these students and their peers and teachers; help with adaptation to the environment thanks to the activities that can be conducted; save time for the acquisition of abilities and skills; favor the diagnostics of the student; back a multisensorial model of communication and training; promotes individualized training that favors the student's progress at his or her own pace, which is highly important for these subjects; favors the development of autonomy and independence; prevents margination; the digital divide, which leads to one being unable of using the instruments of development from the society of knowledge; eases the socio-occupational integration of the students who have specific difficulties; provides moments of leisure; saves time for the acquisition of abilities and skills; the exercises that the students must do can be executed and repeated with minimum efforts so that the students acquire the competences, attitudes and capabilities; favors bridging the gap between these individuals and people in the scientific and cultural worlds; or they can be excellent stimulators (Toledo, 2013).

Authors such as Luque \& Rodríguez (2009) mention that among the future actions needed for an adequate implementation of the ICT, we find the integration of the technology in the classroom for students with disabilities and the development of research on the methodology and the didactics for the application of the ICT with these students. In the studies that relate the ICT with its possibilities for students with special education needs due to disability, the potential of the ICT for contributing to a better quality of life of students with functional diversity, is made evident (Altinay \& Altinay, 2015; Turner-Cmuchal \& Aitken, 2016; Vladimirovna \& Sergeevna, 2015; Alper \& Goggin, 2017; Hollier, 2017).

In this context, the teachers have to be trained with a set of knowledge and skills that allow them, on the one hand, to understand and master different technological resources, and on the 
other, to achieve their integration in their didactic practice in the classroom. This implies the necessity of possessing a series of competences that will allow for the implementation of the ICT in the process of teaching-learning (Almerich, Suarez, Orellana, \& Díaz 2010).

Within the context in Spain in the last few years, research works have been developed that are related to the initial training of the teachers, and their technological competence and disability (Morales \& Llorente Cejudo, 1916; Cabero, Fernández Batanero, \& Barroso, 2016). That said, with respect to the active teachers, it should be first pointed out that there is a strong marginality of the works that address the problem of training on the ICT and the competences that these teachers need in their daily practice to be able to use them with disabled individuals. On the other hand, the research conducted evidence the lack of training and knowledge these teachers have with respect to the different types of technologies that could be used. (Roig, Ferrández, Rodríguez-Cano, \& Crespo, 2012; Suriá, Martínez \& Ordoñez, 2014; Tello \& Cascales, 2015). This aspect negatively impacts the use of the ICT, thereby preventing the accessibility of information and the promoting of the individual's capacities, which in the case of individuals with disabilities, could help alleviate their difficulties and in some cases, reduce their limitations to a minimum (Homero, Tejedor, \& Calvo, 2017).

\subsection{Methodology}

To reach these goals, an exploratory study was conducted in the second trimester of 2017. The study of the design was post-facto descriptive, with an accidental non-probabilistic sample. The objectives of the study were: to learn, through the use of a questionnaire, the degree of technological training and knowledge that Primary School teachers have with respect to the use of the ICT for individuals with different types of disabilities. Analyze if this degree of technological training and knowledge is determined by variables such as gender, age, years of teaching experience, education degree, and specialty studied in their initial teacher's training.

The study sample was comprised by 777 teachers from primary schools from the 17 Autonomous Communities in Spain, 
with most of these centers being public ( $\mathrm{f}=588,75.68 \%)$, followed by subsidized schools ( $\mathrm{f}=141,18.15 \%)$ and 48 private schools (6.18\%). Of these 777 teachers, $216(27.80 \%)$ were men and 561 (72.20\%) women. $25.48 \%(\mathrm{f}=198)$ were less than 30 years old, 27.84\% ( $\mathrm{f}=294)$ were aged between 31 and 40, 30.89\% ( $\mathrm{f}=240)$ were aged between 41 and 55, and 5.79\% ( $\mathrm{f}=45)$ were older than 55 years of age. A little over 35\% (35.14\%, $\mathrm{f}=275)$ had between 1 and 5 years of teaching experience, followed by $18.15 \%(\mathrm{f}=141)$ who had between 16 and 25\% years of experience.

Most of these teachers $(43.24 \%, \mathrm{f}=336)$ were career civil servants, followed by $19.31 \%$ ( $\mathrm{f}=150)$ who were interim staff, with the least number of teachers being substitute teacher $(2.70 \%, \mathrm{f}=33)$.

\subsection{Data collection instrument}

For data collection, an "ad hoc" questionnaire was utilized, comprised by 53 items with a Likert-type scale with six answer options, which collected information on the following dimensions: general perception of the use of the ICT with people with functional diversity (10 items), ICT for people with visual disability (9 items), ICT for people with hearing disability (9 items), ICT for people with motor disability (7 items), ICT for people with cognitive disability (8 items), and accessibility (7 items).

Table 1 shows the values of Cronbach's alpha obtained, for the instrument overall as well as its different dimensions

Table 1. Cronbach's alpha values

\begin{tabular}{lc}
\hline Dimension & Cronbach's Alpha \\
\hline Total scale & 0.993 \\
\hline General aspects scale & 0.967 \\
\hline Visual deficiency scale & 0.986 \\
\hline Hearing deficiency scale & 0.983 \\
\hline Movement deficiency scale & 0.982 \\
\hline Cognitive deficiency scale & 0.979 \\
\hline Accesibility scale & 0.967 \\
\hline
\end{tabular}


The values could be considered "very high", and thus indicate high levels of reliability of the scale and the dimensions that comprise it (O'Dwyer \& Bernauer, 2014).

The questionnaire was administered online, and can be viewed at <https://docs.google.com/forms/d/e/1FAIpQLSfux6m1cU6Nf-69eiiMS28LjcSom38yqe2OmS-Jy4mXAgJVnA/ viewform>.

\subsection{Results}

The data shows that the mean score reached for the instrument overall was 3.26 , with a standard deviation of 1.28 . This score could indicate that the teachers in the sample considered themselves to be experienced in the use of the ICT with students with functional diversity. This training was better in the "general" perspective (3.70) and in the use with subjects with cognitive (3.45), motor (3.29), and hearing (3.02); on the other hand, the lowest scores were obtained by the knowledge the teachers indicated as having with respect to accessibility (2.85) and the use of technologies with people with "visual" deficits (3.02).

The teachers were asked to score themselves from 0 to 10 on the knowledge they thought to have with respect to the technical and educational management of the audiovisual, computer and internet media; the results are shown in table 2.

Table 2. Assessment of the teachers with respect to their knowledge on the technical and educational management of the different ICT

\begin{tabular}{lcc}
\hline & Mean & Std. Dev. \\
\hline $\begin{array}{l}\text { How do you rate your training on the technical management of au- } \\
\text { diovisual and computer technologies? }\end{array}$ & 6.58 & 1.92 \\
\hline $\begin{array}{l}\text { How do you rate your training for the educational use of audiovisual } \\
\text { and computer technologies? }\end{array}$ & 6.44 & 1.87 \\
\hline How do you rate your training on the technical use of the Internet? & 7.05 & 1.90 \\
\hline How do you rate your training for the educational use of the Internet? & 6.84 & 2.00 \\
\hline
\end{tabular}

The results indicated that the teachers seemed to have certain knowledge on the use of the ICT, although their use of the Inter- 
net was greater than the audiovisual or computer resources and higher in the technical use as compared to the educational use.

One of the objectives of the present research study was to understand if there was a relationship between the level of training/ knowledge of the teachers on the use of the ICT with students with diverse disabilities, and the teacher's own perspective on their training on the technical management and for the educational use of the audiovisual, computer and internet technologies. Pearson's correlation coefficient was used, with the scores shown in table 3.

Table 3. Correlations between the technical and educational domains of the audiovisual, computer and internet media and their mastery for the educational use of the ICT with students with functional disabilities $\left({ }^{*} p \leq .05-{ }^{* *} p \leq .01\right)$. T.M. AV-Co (Technical mastery audiovisual-computer); E.M. AV-Co (Educational mastery audiovisual-computer); T.M. Int (Technical mastery Internet); E.M. Int (Educational mastery Internet)

\begin{tabular}{|c|c|c|c|c|c|}
\hline & & T.M. AV-Co & E.M. AV-Co & T.M. Int & E.M. Int \\
\hline \multirow[t]{2}{*}{ General } & Pearson's Correlation & $.106^{* \prime}$ & $.149^{*}$ & $.192^{*}$ & $.209^{*}$ \\
\hline & Sig.(bilateral) & 0.003 & 0.000 & 0.000 & 0.000 \\
\hline \multirow[t]{2}{*}{ Visual } & Pearson's Correlation & 0.036 & $.080^{\circ}$ & $.099^{*}$ & $.111^{* *}$ \\
\hline & Sig.(bilateral) & 0.314 & 0.026 & 0.006 & 0.002 \\
\hline \multirow[t]{2}{*}{ Hearing } & Pearson's Correlation & $.090^{\circ}$ & $.130 "$ & $.140^{* \prime}$ & $.156^{* \prime}$ \\
\hline & Sig.(bilateral) & 0.012 & 0.000 & 0.000 & 0.000 \\
\hline \multirow[t]{2}{*}{ Motor } & Pearson's Correlation & $.072^{\circ}$ & $.088^{\circ}$ & $.111^{* \prime}$ & $.101^{*}$ \\
\hline & Sig.(bilateral) & 0.044 & 0.015 & 0.002 & 0.005 \\
\hline \multirow[t]{2}{*}{ Cognitive } & Pearson's Correlation & $.084^{\circ}$ & $.097^{* *}$ & $.140 "$ & $.152^{* \prime}$ \\
\hline & Sig.(bilateral) & 0.019 & 0.007 & 0.000 & 0.000 \\
\hline \multirow[t]{2}{*}{ Accessibility } & Pearson's Correlation & 0.053 & $.088^{\circ}$ & $.134 "$ & $.123^{* *}$ \\
\hline & Sig.(bilateral) & 0.144 & 0.014 & 0.000 & 0.001 \\
\hline \multirow[t]{2}{*}{ Total } & Pearson's Correlation & $.079^{\circ}$ & $.115^{*}$ & $.148^{* \prime}$ & $.156^{*}$ \\
\hline & Sig.(bilateral) & 0.027 & 0.001 & 0.000 & 0,000 \\
\hline
\end{tabular}


The results were split three ways: in first place, there were primarily significant relationships between the technical and educational mastery of the audiovisual, computer and internet media, and the mastery the teachers point to having on the use of the ICT with students with functional diversity, in general as well as for different types; in second place, the correlations are positive, so that when a variable increases, the other does as well in the same direction; and in third place, and in agreement with Mateo (2004), these correlations are very low.

As for the existence of significant relationships between the knowledge mentioned by the different teachers on the different dimensions that were asked about in the questionnaire (general, visual, hearing...etc.) a new Pearson's correlation coefficient was used, with the values shown in table 4.

Table 4. Correlations between the different dimensions in the questionnaire. $\left({ }^{* *} p \leq .01\right)$.

\begin{tabular}{lc}
\hline Dimensions compared & Correlation \\
\hline General-Visual & $.738^{* *}$ \\
\hline General-Hearing & $.775^{* *}$ \\
\hline General-Motor & $.744^{* *}$ \\
\hline General-Cognitive & $.770^{* *}$ \\
\hline General-Accessibility & $.676^{* *}$ \\
\hline Visual-Hearing & $.814^{* *}$ \\
\hline Visual-Motor & $.804^{* *}$ \\
\hline Visual-Cognitive & $.742^{* *}$ \\
\hline Visual-Accessibility & $.773^{* *}$ \\
\hline Hearing-Motor & $.865^{* *}$ \\
\hline Hearing-Cognitive & $.832^{* *}$ \\
\hline Hearing -Accessibility & $.753^{* *}$ \\
\hline Motor-Cognitive & $.837^{* *}$ \\
\hline Motor-Accessibility & $.774^{* *}$ \\
\hline Cognitive-Accessibility & $.728^{* *}$ \\
\hline
\end{tabular}


In this case, the results showed that all the correlations were positive and significant to ${ }^{* *} \mathrm{p} \leq .001$, and very high. In other terms, the teachers who indicated being trained in one of the dimensions were also trained in the others.

With the objective of delving into the possible relationships between training in the dimensions examined in the questionnaire, the following hypotheses were formulated:

- Null hypothesis (H0): There are no significant differences with an alpha risk of rejecting the hypothesis of 0.05 , or less between the different dimensions compared.

- Alternative hypothesis (H1): There are significant differences with an alpha risk rejecting the hypothesis of 0.05 or less between the dimensions compared.

For this, the Student's t-test was used. The resulting values, for 776 degrees of freedom, are presented in table 5.

Table 5. Student's t-test values between the different dimensions examined in the questionnaire. $\left({ }^{* *} p \leq .01\right)$

\begin{tabular}{lc}
\hline \multicolumn{1}{c}{ Dimensions compared } & $\mathrm{t}$ \\
\hline General-Visual & $19.529^{* *}$ \\
\hline General-Hearing & $14.617^{* *}$ \\
\hline General-Motor & $10.846^{* *}$ \\
\hline General-Cognitive & $6.855^{* *}$ \\
\hline General-Accessibility & $21.973^{* *}$ \\
\hline Visual-Hearing & $-5.766^{* *}$ \\
\hline Visual-Motor & $-8.164^{* *}$ \\
\hline Visual-Cognitive & $-11.349^{* *}$ \\
\hline Visual-Accessibility & $5.028^{* *}$ \\
\hline Hearing-Motor & $-3.170^{* *}$ \\
\hline Hearing-Cognitive & $-7.952^{* *}$ \\
\hline Hearing - Accessibility & $9.683^{* *}$ \\
\hline Motor-Cognitive & $-5.093^{* *}$ \\
\hline Motor-Accessibility & $12.375^{* *}$ \\
\hline Cognitive- Accessibility & $15.380^{* *}$ \\
\hline
\end{tabular}


The resulting values led to the rejection of all the $\mathrm{HO}$, so that it could be concluded that there were statistically-significantly differences as well as an alpha risk of rejecting the H0 of $\mathrm{p} \leq .001$, with respect to the knowledge shown by the teachers on the different types of knowledge on the use of the ICT with individuals with different types of functional diversity.

Another of the hypothesis referred to the existence of differences in the knowledge as a function of the gender of the 216 male teachers and the 561 female ones, with the means shown in table 6 .

Table 6. Values reached as a function of the teacher's gender

\begin{tabular}{lll}
\hline \multirow{2}{*}{ General } & Gender & Mean \\
\hline \multirow{2}{*}{ Visual } & Male & 3.6000 \\
\cline { 2 - 3 } & Female & 3.7326 \\
\hline Hearing & Male & 2.8356 \\
\cline { 2 - 3 } & Female & 3.0914 \\
\hline Motor & Male & 2.8920 \\
\cline { 2 - 3 } & Female & 3.3244 \\
\hline Cognitive & Male & 3.2560 \\
\cline { 2 - 3 } & Female & 3.3086 \\
\hline Accessibility & Male & 3.1337 \\
\cline { 2 - 3 } & Female & 3.5782 \\
\hline Total & Male & 2.8869 \\
\cline { 2 - 3 } & Female & 2.8304 \\
\hline & Male & 3.0967 \\
\hline & Female & 3.3196 \\
\hline
\end{tabular}

As shown in the mean values, they tended to be higher for the women than for the men, except for the dimension "accessibility".

In order to analyze if the differences found were significant from a statistical point of view, a Student's t-test was used for independent samples, although before this, a Levene's test was used to analyze the equality of the variances (homoscedasticity), and as a function of the significance value obtained, to determine the 
$\mathrm{t}$-value that should be used. Table 8 shows the values obtained and the degree of significance in order to accept or reject the H0, which referred to the non-existence of significant differences.

Table 7. Differences as a function of gender of the teachers. $\left({ }^{* *} p \leq .01\right)$

\begin{tabular}{|c|c|c|c|c|c|c|}
\hline & \multirow[b]{2}{*}{$\mathrm{F}$} & \multicolumn{2}{|c|}{ Levene's test } & \multirow[b]{2}{*}{ Df } & \multirow[b]{2}{*}{ Sig. } & \multirow[b]{3}{*}{.148} \\
\hline & & Sig. & $\mathrm{t}$ & & & \\
\hline \multirow[t]{2}{*}{ General } & Equal variances are assumed & 1.582 & .209 & -1.447 & 775 & \\
\hline & Equal variances are not assumed & & & -1.500 & 420.348 & .134 \\
\hline \multirow[t]{2}{*}{ Visual } & Equal variances are assumed & 20.998 & .000 & -2.253 & 775 & .025 \\
\hline & Equal variances are not assumed & & & -2.459 & 472.723 & $.014^{* *}$ \\
\hline \multirow[t]{2}{*}{ Hearing } & Equal variances are assumed & 8.248 & .004 & -3.667 & 775 & .000 \\
\hline & Equal variances are not assumed & & & -3.898 & 444.653 & $.000^{* *}$ \\
\hline \multirow[t]{2}{*}{ Motor } & Equal variances are assumed & 3.106 & .078 & -.426 & 775 & .670 \\
\hline & Equal variances are not assumed & & & -.441 & 420.314 & .659 \\
\hline \multirow[t]{2}{*}{ Cognitive } & Equal variances are assumed & .618 & .432 & -3.641 & 775 & .000 \\
\hline & Equal variances are not assumed & & & -3.702 & 403.679 & $.000^{* *}$ \\
\hline \multirow[t]{2}{*}{ Accessibility } & Equal variances are assumed & 6.028 & .014 & .488 & 775 & .626 \\
\hline & Equal variances are not assumed & & & .519 & 445.475 & .604 \\
\hline \multirow[t]{2}{*}{ Total } & Equal variances are assumed & 7.550 & .006 & -2.181 & 775 & $.029^{* *}$ \\
\hline & Equal variances are not assumed & & & -2.326 & 447.749 & .020 \\
\hline
\end{tabular}

The results did not lead to the rejection of the H0 that referred to the non-existence of statistically-significant differences to $\mathrm{p} \leq$ .05 or less in the following dimensions: general knowledge, application of the ICT for people with motor deficit and accessibility. On the other hand, there were significant differences in the following dimensions: visual, hearing and cognitive. It should be mentioned that the $\mathrm{HO}$ was also rejected in the scores found for the instrument overall. In every case, the female teachers had greater knowledge than the men on the useof the ICT with people with functional diversity.

To analyze if there were statistically-significant differences as a function of the teacher's ages, an ANOVA was used (table 8). 
Table 8. ANOVA as a function of the teacher's ages $\left({ }^{* *} p \leq .01\right)$

\begin{tabular}{|c|c|c|c|c|c|c|}
\hline & & $\begin{array}{l}\text { Sum of } \\
\text { squares }\end{array}$ & Df & $\begin{array}{c}\text { Quadratic } \\
\text { mean }\end{array}$ & $\mathrm{F}$ & Sig. \\
\hline \multirow[t]{3}{*}{ General } & Among groups & 66.650 & 3 & 22.217 & 18.059 & $.000^{* *}$ \\
\hline & Within groups & 950.966 & 773 & 1.230 & & \\
\hline & Total & 1017.616 & 776 & & & \\
\hline \multirow[t]{3}{*}{ Visual } & Among groups & 84.361 & 3 & 28.120 & 14.656 & $.000^{* *}$ \\
\hline & Within groups & 1483.091 & 773 & 1.919 & & \\
\hline & Total & 1567.452 & 776 & & & \\
\hline \multirow[t]{3}{*}{ Hearing } & Among groups & 146.115 & 3 & 48.705 & 24.070 & $.000^{* *}$ \\
\hline & Within groups & 1564.151 & 773 & 2.023 & & \\
\hline & Total & 1710.266 & 776 & & & \\
\hline \multirow[t]{3}{*}{ Motor } & Among groups & 144.282 & 3 & 48.094 & 21.786 & $.000^{* *}$ \\
\hline & Within groups & 1706.419 & 773 & 2.208 & & \\
\hline & Total & 1850.702 & 776 & & & \\
\hline \multirow[t]{3}{*}{ Cognitive } & Among groups & 148.903 & 3 & 49.634 & 22.790 & $.000^{* *}$ \\
\hline & Within groups & 1683.529 & 773 & 2.178 & & \\
\hline & Total & 1832.432 & 776 & & & \\
\hline \multirow[t]{3}{*}{ Accessibility } & Among groups & 47.184 & 3 & 15.728 & 7.732 & $.000^{* *}$ \\
\hline & Within groups & 1572.476 & 773 & 2.034 & & \\
\hline & Total & 1619.661 & 776 & & & \\
\hline \multirow[t]{3}{*}{ Total } & Among groups & 94.008 & 3 & 31.336 & 20.591 & $.000^{* *}$ \\
\hline & Within groups & 1176.355 & 773 & 1.522 & & \\
\hline & Total & 1270.362 & 776 & & & \\
\hline
\end{tabular}

The results allowed for the rejection of all the Ho formulated that referred to the non-existence of significant differences as a function of the teacher's age, to significance level of $\mathrm{p} \leq .01$, with respect to the knowledge the teachers mentioned having on the application of the ICT for individuals with functional diversity. These differences were found in their general knowledge, as well as the one possessed by the different types of diversity.

In order to understand if there were differences between the different age groups, a "Post-Hoc" ANOVA analysis was applied 
for multiple comparisons (Miller, 1997) (Table 9). It should be noted, that to not over-explain on the results, and as they were very similar, only the data collected when the test was applied to the entire instrument are shown.

Table 9. Post-test of multiple comparisons for the differences obtained as a function of age

\begin{tabular}{llccc}
\hline \multicolumn{1}{c}{ Age } & \multicolumn{1}{c}{ Age } & $\begin{array}{c}\text { Differences in } \\
\text { means }\end{array}$ & $\begin{array}{c}\text { Standard } \\
\text { error }\end{array}$ & Sig \\
\hline \multirow{2}{*}{ Younger than 30} & Between 31 and 40 & .44349 & .11341 & $.000^{* *}$ \\
\cline { 2 - 5 } & Between 41 and 55 & .72222 & .11843 & $.000^{* *}$ \\
\cline { 2 - 5 } & Older than 55 & 1.34934 & .20372 & $.000^{* *}$ \\
\hline Between 31 and 40 & Younger than 30 & -.44349 & .11341 & $.000^{* *}$ \\
\cline { 2 - 5 } & Between 41 and 55 & .27873 & .10732 & $.010^{* *}$ \\
\cline { 2 - 5 } & Older than 55 & .90585 & .19747 & $.000^{* *}$ \\
\hline Between 41 and 55 & Younger than 30 & -.72222 & .11843 & $.000^{* *}$ \\
\cline { 2 - 5 } & Between 31 and 40 & -.27873 & .10732 & $.010^{* *}$ \\
\cline { 2 - 5 } & Older than 55 & .62712 & .20040 & $.002^{* *}$ \\
\hline \multirow{2}{*}{ Older than 55 } & Younger than 30 & -1.34934 & .20372 & $.000^{* *}$ \\
\cline { 2 - 5 } & Between 31 and 40 & -.90585 & .19747 & $.000^{* *}$ \\
\cline { 2 - 5 } & Between 41 and 55 & -.62712 & .20040 & $.002^{* *}$ \\
\hline
\end{tabular}

As it can be observed, differences were fundamentally shown between the younger professors with respect to the older ones. Thus, it could be said that the 10-year cutoff used was enough for establishing differences in the knowledge the teachers indicated as having on the application of the ICT with individuals with functional diversity.

\subsection{Conclusions}

The conclusions derived from the data presented, in relation to the objectives proposed, reveal interesting aspects such as: 
- The teachers highly believe that ICT are useful resources for the training of people with disabilities. However, their technical management and educational use of the ICT, computers and the Internet had an effect on the knowledge they mentioned having on the use of the ICT with individuals with disabilities. This knowledge was not sufficient, according to the teaching staff.

- The low level of training indicated was on the general overview as well as the specific application to individuals with disabilities: Visual, Hearing, Motor and Cognitive, as well as to accessible design and accessibility. These low scores are the result of the little training received.

- The female teachers were perceived as having more knowledge than the male teachers.

- The age of the teachers and the years of experience had an effect on the level of knowledge on the use of the ICT with people with disabilities. In this sense, in both cases the younger teachers mentioned having more knowledge. This could be due to these younger students having finished their studies very recently, which coincided with the recent addition of training on the use of the ICT with people with disabilities in the curriculum. This interest could have been fed by the recent appearance of manuals on the ICT and disabilities in different universities in Spain, in Masters' degree in special education, etc.

As for the limitations of this research work, three can be highlighted only information on the teaching staff was collected, and it would be important to collect information on the educational center's directors as well.

\section{References}

Almerich, G., Suárez, J. M., Orellana, N., \& Díaz, M.I. (2010). Relationship between the integration of information and communication technologies and knowledge of them, Revista de Investigación Educati$v a, 28$ (1), 31-50.

Alper, M. \& Goggin, G. (2017). Digital technology and rights in the lives of children with disabilities, New Media \& Society. Avalailable at <http://journals.sagepub.com/doi/full/10.1177/1461444816686323>. 
Altinay A. \& Altinay, Z. (2015). Examination on ICT integration into Special Education Schools for Developing Countries, TOJET: The Turkish Online Journal of Educational Technology, 14 (3), 70-72.

Cabero, J., Fernández Batanero, J. M. \& Barroso, O. (2016). Students of the Teaching degree: ICT and disability, Revista Electrónica de Investigación Educativa, 18 (3), 106-120. Avalailable at <http://redie.uabc. $\mathrm{mx} /$ redie/article/view/965>.

Cabero, J., Fernández Batanero, J. M. \& Córdoba, M. (2016). Knowledge of the ICT applied to individuals with disabilities. Construction of a diagnostics instrument, Magis, Revista Internacional de Investigación en Educación, 8, 17, 157-176. doi: 10.11144/Javeriana.m8-17.ctap.

Hollier, S. (2017). Technology, education and access: A 'fair go' for people with disabilities. 14th International Web for All Conference, W4A.

Homero, G., Tejedor, F. J., \& Calvo, M. I. (2017). Meta-analysis on the effect of education software on students with special education needs, Revista de Investigación Educativa, 35 (1), 35-52.

Luque, D. \& Rodríguez, G. (2009). Information and Communication Technology used with disabled students: a teaching approach, Revista Iberoamericana de Educación, 49 (3), 1-8.

Mateo, J. (2004). Ex post-facto research. In Rafael Bisquerra-Alzina (coord.), Metodología de la investigación educativa. Madrid: La Muralla, (195-230).

Morales, P. T. \& Llorente Cejudo, M. C. (2016). Initial training of the teaching staff on the use of Information and Communication Technologies (ICT) for the education of the disabled, Digital Education Review, 30, 123-134.

O'Dwyer, L. \& Bernauer, J. (2014). Quantitative Research for the Qualitative Researcher. California: Sage.

Roig, R.; Ferrández, S.; Rodríguez-Cano, C., \& Crespo, M. (2012). The use of the ICT in the Special Education Classroom: teacher's perception. In Navarro, J., Fernández, M. T., Soto, F. J., \& Tortosa, F. (coords.), Flexible responses in diverse educational contexts. Murcia: Consejería de Educación, Formación y Empleo. Avalailable at <http://diversidad. murciaeduca.es/publicaciones/dea2012/docs/ rroig.pdf>.

Suriá, R., Martínez, D., \& Ordoñez, T. (2014). ICT, teaching and disability: do teachers feel prepare to support disabled students in the use of the ICT in the classrooms? In Arnaiz, P., Hurtado, M. D., \& Soto, F. J. (coords.) 25 Años de integración escolar en España: tecnología e inclusión en el ámbito educativo, laboral y comunitario. Murcia: Consejería de Educación, Formación y Empleo. 
Tello, I. \& Cascales, A. (2015). The ICT and specific needs of educational support: analysis of the teacher's ICT competences, RIED, 18 (2), 355-383.

Toledo, P. (2013). The technologies of information, communication and inclusive education. In Nuevos escenarios digitales. las tecnologías de la información y la comunicación aplicadas a la formación y desarrollo curricular. Madrid: Pirámide, pp. 411-427.

Turner-Cmuchal, M. \& Aitken, S. (2016). ICT as a tool for supporting inclusive learning opportunities, Perspectivas Internacionales sobre la Educación Inclusiva, 8, 159-180.

Vladimirovna, S. \& Sergeevna, O. (2015). Features of the Information and Communication Technology Application by the Subjects of Special Education, International Education Studies, 8 (6). Available at $<$ http://10.5539/ies.v8n6p162>. 